\title{
The Potential of Foreign News as International Development Communication
}

\author{
Bella Mody ${ }^{1}$
}

\begin{abstract}
This article investigates what the news says about inequity-driven civil wars and economic underdevelopment. Dewey argued that the lack of causal knowledge that distinguishes between symptoms and root causes would limit potential effective and transformative public action. Political scientists have demonstrated that increases in just the number of news stories about a foreign country in both US print and TV news in one year produced a clearly significant relationship to increases in commitments of US foreign aid the following year. This study of reporting on a 2003-2005 African crisis by ten news organizations over 26 months found few articles predominantly focused on causes against conditions on the ground or remedies. It raises questions about the conditions under which news organizations might be expected to provide causal knowledge and when such information can lead to more enlightened long term aid for national transformation.
\end{abstract}

Keywords: foreign news, international development communication, China, Egypt, South Africa, Qatar

\section{Introduction}

The practice of communication for development has been accompanied by calls for reflexive critique of communication about development in the field of development communication (Wilkins and Mody 2001). The UNDP Human Development Report of 2005 focused on how civil wars were a major cause of declines in development (UNDP 2005). Research continues to show the negative effects of civil wars on development, e.g. military expenditure drains resources, financial instability leads to conflict (and vice versa), war retards the development of financial institutions/infrastructure, and interactions between finance and conflict are exacerbated by distributional struggles (Baddaley 2011). This article reports on what the news says about economic underdevelopment, equity-driven civil wars, and state repression, in the context of a larger study on the geopolitics of news (Mody 2010) that asked: what kind of knowledge about the foreign is provided by different national journalisms and news organizations around the world?

Why study foreign news about civil wars and underdevelopment as international development communication? Amount of news coverage has been found to be a major predictor of knowledge of international affairs (Price and Czilli 1996). In the 1970s, post-World War II states of the global South focused on being presented fairly in the news, with coverage of both strengths and weaknesses. Political scientist Van Belle 
(2004) and colleagues demonstrated that increases in just the number of news stories about a foreign country in both US print and TV news in one year (1988) produced a clearly significant relationship with increases in commitments of US foreign aid the following year (1989). For foreign aid bureaucrats and politicians, level of coverage was both an indicator of domestic interest and a causal force. They also showed that unreported disasters of similar human impact received less aid. This is consistent with McCombs and Shaw's agenda-setting hypothesis (1972). The increase in state-owned international satellite broadcasting channels like France 24, Russia Today, and Telesur speaks to the recognition of foreign news as soft power that influences foreign public opinion and decision makers.

In The Public and Its Problems, Dewey (1927) argued that the lack of causal knowledge that distinguishes between symptoms and root causes would limit potential effective and transformative public action to no more than clamorous public reaction. Among the factors that led to distortions in public perceptions, Lippmann (1922) included the pressure on the media to express complex events in short messages, resulting in news which signals events but does not explain them in their complexity and context.

Studies of communication for development have conceptualized development and development support communication as a national domestic phenomenon, impacted by foreign forces like aid and trade. This article looks at the global as against the local, at foreign news about a country that shapes the opinions of the donor public and the aid, trade, and development decisions of their foreign policy makers. The lack of ideas and explanation about root causes of underdevelopment, civil war, and state collapse could lead to conceptualization of aid as merely short-term problem-solving help rather than investment in social transformation and state building over the long term. Causal analysis in foreign news could enable the donor-public in the global North to discriminate between one crisis and another. In the above-mentioned study on the geopolitics of news (Mody 2010), our assumption was that foreign news reports could present an in-depth understanding of the deep-rooted historical causes of underdevelopment and civil wars in young post-World War II states, pre-empt the slide backwards on the UNDP Human Development Index that is taking place in many African countries, and thus have the potential to enable long term aid support for national transformation. Inclusive nationbuilding, health, education, and welfare take decades to achieve.

The article is divided into five sections: underdevelopment in young states, news about the causes of underdevelopment and civil wars, the case of Darfur Sudan, research findings, and implications for foreign news and international development communication.

\section{Underdevelopment in Post-World War II States}

States born after the World War II wave of decolonization are physical agglomerations of sub-national ethnic kingdoms. While they received guarantees of sovereignty and territorial integrity from the United Nations (UN), they were immediately expected to meet the UN Declaration of Human Rights based on norms that had evolved over hundreds of years in Europe. While coping with the integration of distinct kingdoms and ethnicities lumped together into single young states by colonizers, governments of the South have also been struggling with the scars of decades of underdevelopment. Some have been unable or unwilling to deliver food, good governance, education, and health 
to all their citizens. These integrationist and human development "growing pains" have been expressed through locally specific political, social, and ethno-nationalist rebellions and high levels of physical violence.

The current situation in the global South in the twenty-first century would appear to be analogous to the period of state-building in Western Europe's decentralized peasant states of the seventeenth and eighteenth centuries as they battled violently over land, emerging only hundreds of years later as representative modern states. Subsequent to independence from colonial rule, young national governments (including electoral democracies) have not always distributed their limited income, education, health care, and development opportunities fairly and equitably, sometimes leading to sub-national rebellions by deprived regions that threaten their sovereignty. The number of civil wars initiated by peripheral parts of young states seeking equitable distribution of social opportunities, cultural autonomy, and political power have increased, e.g., the Tamils of Sri Lanka, Telengana in South India, Tibet in China, the Karen in Burma. Many marginalized ethnic groups do not have the resources to fight, e.g., the Rohingya Muslims from North West Burma who are denied citizenship and are considered illegals or refugees in Bengali-speaking Bangladesh. Several embryonic states teeter on the brink, e.g., Abkhazia, South Ossetia, Nagorno-Karabakh, Western Sahara. Sri Lanka used military force to destroy the Tamil Tigers, suspended the legislature, and declared a state of emergency. For the most part, warfare is now a means to achieve political ends within countries (Crocker et al. 2007).

\section{Causes of Underdevelopment}

The dominant Western explanations of the causes of poverty in Africa focus on internal, local, and contemporary issues. While civil wars, corruption, and incompetent institutions are mentioned in mainstream history, there is no mention of the interruption through foreign colonization and the introduction of Western capitalism and class relations. The political independence of former colonies is discussed solely in terms of the difficulty of shaping a modern sovereign state out of building blocks based on clan, kinship, and tribe. This explanation does not contextualize conditions in the South in terms of the prior international order of structured injustices and exploitation. Hunger, disease, death, and illiteracy are symptoms of more basic structural causes (e.g., unfair distribution of agricultural land or national oil profits) that need to be explained in terms of historical settings and global interconnections, namely, that the affluence of the West is related to the poverty of Africa. Western consumers do not know about the conditions of life in Kenya or Mozambique from where they buy packaged beans and nuts. Academic explanations of underdevelopment that pointed to global structure and inequality of economic resources in the 1960s and 1970s were displaced by attention to knowledge, power, and language dimensions of Western domination in the 1980s and 1990s. Post-structuralism, post-modernism, and post-Marxism placed the culture, identity, and resources of local people at the center of their explanations rather than the global and national relations of power that cause such variations. 


\section{Causes of Underdevelopment in the News}

Decades after pleas by countries in the global South for a New World Information and Communication order, recent studies (Robins 2003) continue to show neglect of the complex and fundamental causes of crises in African states. Most foreign newspapers entrust coverage of Africa to stringers and wire services except in times of major crises. Research has found that Western press coverage does not benefit from background reporting in African press coverage of their own crises, e.g., coverage of the Rwanda genocide in the Nigerian Guardian and Kenya's Daily Nation (Alozie 2007). Contextual information explaining the causes of crises is available in the national press, but editors in the North have found it is of little interest to their readers.

The challenge of covering the global South comprehensively is illustrated by the ahistorical coverage of the January 2010 earthquake in Haiti. The focus was on the poverty that limited the country's remedial response, without mentioning the historical foreign causes of this inability: France forcing the hemisphere's second Republic (declared in 1804) to incur massive debt to pay for the loss of French property during the revolution; the US occupation in 1915; neo-liberal aid and trade "adjustment" policies of the IMF and US that forced small farmers off the land into Port-au-Prince's sweatshops as a lowcost offshore labor force for North American corporations; the internationally sponsored coup in 2004 that overthrew Jean-Bertrand Aristide elected by over 70 percent of Haiti's electorate; or the blocking in the Security Council of any expansion of the UN mission's mandate since 2005 to include employment generation and infrastructure development.

The press has also been blamed for not alerting the world to the genocidal conditions leading up to the massacre in Rwanda and for failing to understand it (Kuperman 2000). The roots of Africa's problems in the colonial period are acknowledged, but the role of current controls like IMF interventions, the arms trade, and commodity prices set by importers in the North appear to be too complex. Decontextualized and excessively ethnicized press representations of Africa obscure the geopolitics of the colonial and postcolonial periods (Carruthers 2004). Misunderstandings by the foreign press have included tribalism and ancient hatreds as explanations for crises in Africa without presenting external historical causes like colonial interventions that led to internal causes; such misdiagnoses have contributed to errors in conceptualizing remedies. Several authors have criticized the inadequacy of explanations of African crises. Carruthers (2004) calls the West's acontextual coverage of Africa "explanatory impoverishment" that serves as a foil for its self-conception, particularly when it implicates Western policies and practices. Leslie Steeves (1997) found blindness to the larger historical context of patriarchy in Kenya's print media reporting on the gang rape of 70 schoolgirls by their male classmates in Meru. Mamdani (2009) has described news representations of Africa as a "pornography of violence," perpetrated by young reporters who reduced complex realities to a simple morality tale.

\section{Underdevelopment in Darfur, Sudan}

Between 1990 and 2003, almost 40 percent of the world's conflicts have been within newly independent states in Africa (UNDP 2005) that are struggling to create governance structures out of regions pock-marked by decades of colonial neglect and induced polarization between ethnic groups. Darfur in western Sudan is the site of one of those 
rebellions. In 2003, western Sudan's unmet regional demands for economic development and political representation burst into the open again, for the third time in two decades. Military facilities and the regional airport in El Fasher were bombed. The military lost more planes in one night than it had in the previous twenty-year civil war with South Sudan. The military dictatorship of Sudanese President Omar al-Bashir responded with disproportionate violence, as it did in response to similar demands for attention from the Nuba mountains and the south: a paramilitary was raised to unleash a scorched-earth campaign against largely undefended farmers who supported the rebellion. Victims of desertification, marginalized nomads fought settled agricultural groups as proxies for the state in exchange for the promise of farmland. The result: 300,000 Darfuri civilians have been killed, millions live in refugee camps. The cycle of underdevelopment continues. A donor meeting in Cairo in April 2010 raised less than half the targeted \$2 billion for development projects in Darfur (Awad 2011). The tragedy could have been avoided if foreign donors of humanitarian relief during frequent famines had encouraged their dictator-ally in Khartoum to open up political power to disenfranchised peripheries in the South, East, and West. After the creation of South Sudan as an independent country, there is a resurgence of civil war in the Southern Kordofan and Blue Nile peripheries, as well as an escalation in Darfur.

What did the news say about Darfur? Journalistic accounts of the Darfur crisis have been found wanting on many counts: little coverage in the first year (2003), a decline in coverage due to the Asian tsunami at the height of the mass murders in December 2004, a focus on the ethnic/tribal roots of the conflict to the exclusion of historical economic and political causes, moral indignation at humanitarian aspects of the crisis, attention to remedies by forces from the global North. My colleagues and students joined me in comparing alternative narratives of Darfur produced by less studied news organizations in Asia (China, Qatar) and Africa (South Africa, Egypt) with reporting by well-studied news organizations in Europe (France, UK) and the US. The focus was on how different news organizations represented the struggle of Darfur in Western Sudan between 2003 and 2005 for equitable treatment by its own national government in Khartoum. What kind of knowledge was provided by news in this internet age of supposed informational abundance? Our intention was to go beyond generalizations about "the media" as a global, regional, or national monolith by studying the specifics of coverage for foreign and domestic audiences by ten news organizations (five state-owned, five privatelyowned) based in seven different countries (three countries in the global North and four countries in the global South), each with differing national interests in Sudan.

This required an integrative theoretical framework bringing together three research literatures that are not usually combined: political economy that led to questions about who owns and operates news organizations, international relations and political communication that led to questions about national interest in the event/topic covered and how it might affect press relations with the state, and analysis of manifest content that is a staple of media research.

\section{Research Method}

The linking of news texts to political and economic national and media-organization contexts drove the selection of two research methods for data collection and analysis: 
contextual analysis of state politics-press relations and quantitative content analysis. Characteristics of news were coded at the level of the individual article. Student researchers coded all articles in English. News in languages other than English (i.e., China Daily, Al-Ahram, and Le Monde) was coded by hired native speakers of the respective languages. To establish the reliability of the code book, the identical 10 percent of selected articles per news organization were coded by a pair of students. Scott's pi (used to measure reliability) ranged from .71 to .94 for all final versions of coded variables.

Selected findings are presented here on numbers of articles and what each news organization said about the causes of the civil war in Darfur. Each article was analyzed for its focal frame(s), defined as the dominant focus of the majority of the article's content. The frames included causes (i.e., historical and present day causes of the Darfur crisis), conduct (i.e., the nature, status, process, and conduct of the crisis), and remedies (i.e., proposed remedies to the crisis including peace talks and negotiations to end the crisis, proposed changes, and aid from governments and nongovernmental organizations, international courts, or African courts). In addition, the headlines and text of the articles were analyzed for the presence of three keywords: "ethnic-race" terms, "genocide," and "oil/petroleum."

Articles that discussed causes were coded for the specific reason(s) that they cited for causing the crisis. The reasons for the crisis consisted of government inequity in terms of the distribution of resources to the Darfur region, scarcity caused by environmental change, ethnic/racial tensions, and access to oil fields. If articles contained multiple reasons, the first two reasons that were mentioned were coded.

\section{Findings}

This section presents findings per news organization and ends by comparing their performance on coverage of causes as a source of information for foreign publics and their governments.

\section{China's People's Daily and China Daily}

China has high national interests in Sudan, based on its need for oil and minerals to fuel continued economic growth and jobs for its population of almost 1.5 billion. In this communist party state, public opinion is not monitored by bureaucrats and decisionmakers to develop citizen-responsive policies; public opinion is cultivated through the two official media under investigation (one intended for foreign publics and the other for domestic consumption) to ensure strong national interests are unimpeded by an internal crisis in a valued market and a source of oil.

Consistent with its roots as a party organ first published in 1948, the state-owned Chinese language People's Daily has remained a propaganda paper; a subsidiary publication called the Global Times is dedicated to international news. The audience is national and reads no language other than Chinese for the most part. The People's Daily decided not to draw the attention of the Chinese public to Khartoum's attempts to put down an internal rebellion against regional unfairness. Darfur coverage only began with the abduction of Chinese workers by Darfuri rebels over a year after the initial rebellion. 
No news article focused predominantly on explaining the causes: $8 \%$ of news articles explained the causes of the crisis in combination with reporting on conditions on the ground and possible remedies. Of a total of only five references to causes, two $(40 \%)$ were mentions of regional inequity. The source of ethnic conflict was attributed to a “certain Western country" (Huang 2004). Stories also suggested that Sudan's abundant oil resources had made the country a pawn of Western powers' economical and political interests (Xin and Xu 2004).

Started in 1981, China Daily is the official organ of the Communist Party written for English speakers at home and abroad. It has greater editorial flexibility than People's Daily because of its unique audience of English readers who can check accounts of events with the International Herald Tribune and other English-language papers. One story focused predominantly on causes; discussion of causes was combined with the daily conduct of the crisis and possible remedies in $18 \%$ of news articles. Although causes were not always discussed at length or used as a focal frame, the coder found thirty-six references to a range of complex causes in the news articles. The most frequently-stated cause (36\% of mentions) was race/ethnicity, followed by $31 \%$ of mentions of both environmental change and regional inequity. Several articles discussed a combination of these issues as causing the crisis, such as race/ethnicity and regional inequity.

\section{Al-Ahram of Egypt}

Egypt has high national interest in what happens to Sudan on its southern border. A peaceful neighboring Sudan helps to ensure that Nile water-sharing agreements are maintained and refugees from the south do not flow in to protest against a Khartoumsupportive Egypt. National press attention to the Darfuri uprising and the strong putdown by the Khartoum government could disturb Egypt's political equation with the al-Bashir regime.

The Arabic daily Al-Ahram ("The Pyramids" in Arabic) that was started in Alexandria in 1876 is the official voice of the ruling party with a high dependence on official sources. Al-Ahram carried less than $1 \%$ of news articles focused exclusively on causes. Approximately $4 \%$ of news articles discussed causes in combination with reports on the daily conduct of the war and potential remedies. When it did mention causes, Al-Ahram usually put the conflict in historical context, describing Darfur's longstanding sources of tension. In news articles, the most frequently-mentioned cause was environmental change, accounting for $38 \%$ of mentions, followed by discussions of why ethnicity and race $(28 \%)$ were misapprehensions by the West. Very few articles used contemporary political analysis that might give offense to the current al-Bashir administration or imply that Khartoum was at fault. Offending a head of state was cause for imprisonment under Mubarak's state of emergency law. Thus, regional inequity in Khartoum's allocation of development resources to Darfur accounted for only $6 \%$ of mentions.

\section{South Africa's Mail \& Guardian Online}

South Africa has a low national interest in Sudan, unlike Egypt and China which need Sudan's minerals, water, and/or oil. However, South Africa was supportive of Sudan in terms of shared historical experience as a former colony committed to the global South position on national sovereignty and non-intervention by foreign powers. Thus, 
along with other states in Africa, it protested the arrest warrant for Sudanese President al-Bashir on charges of crimes against humanity in Darfur.

The Mail \& Guardian Online is privately owned, benefits from articles from its former majority owner the Guardian of UK, and is edited for a globally-dispersed African and Africanist readership. Africa's first online daily, the Mail \& Guardian originated with the Weekly Mail, a progressive news organization born of resistance to apartheid. Purchased in part by the politically supportive Guardian of London in 1995, 87.5 percent is now owned by Trevor Ncube's Newtrust Company Botswana Limited. The readership is educated left-of-center South Africans, at home and overseas. Coverage began nine months after the uprising, in November 2003. Only one news article dealt predominantly with causes. Causes alone and in combination with other foci were emphasized in $16 \%$ of news articles. The most frequently discussed cause of the conflict was racial or ethnic tensions, accounting for $47 \%$ of total mentions. Regional discrimination and inequitable distribution of resources by the Sudanese government accounted for $37 \%$ of all mentions of cause. Environmental change and related disputes over resources were addressed in $11 \%$ of all causal mentions. Oil was discussed as a cause only in one article although issues surrounding Sudan as an oil-rich country were mentioned in the text of $16 \%$ of news articles.

\section{The UK's Guardian and BBC.co.uk}

The UK maintains strong ties with Sudan, continuing a relationship that dates back to the nineteenth century, including an eighty-year period of joint British-Egyptian colonial rule. The UK's national interest in Sudan is low. Its position on Darfur has been limited to resolutions pressuring the Khartoum government in the UN and the International Criminal Court (ICC), with support for intervention by multilateral organizations like the UN and the African Union (AU).

The Guardian's coverage of international crises has shown comprehensive coverage and significant attention to stories that have been neglected by other newspapers, according to previous research. First published in 1821 by a reformist civil liberties group, the Guardian was purchased by long-time editor Charles Scott in the early 1900s. Now owned by the Scott Trust Limited, this less-than-profitable newspaper is subsidized by other firms in the Guardian Media Group to protect its editorial independence. Its liberal-leaning editorial policy has found support among Labor Party sympathizers, young readers, and the Wikileaks organization.

There were no news articles that addressed causes exclusively. Just over $21 \%$ of news articles addressed causes in combination with the conduct of the war (e.g., aerial bombing, burned villages, dead men, raped women, starving children) and/or possible remedies. Of the total mentions of causes, ethnicity and race-related issues were mentioned most often as causes in the news articles (38\%). Government inequity in the distribution of resources was the second most frequently-mentioned cause of conflict, accounting for $35 \%$ of references to cause in news articles. Environmental change was the third most frequently-mentioned cause (15\%). Explicit mention of oil as a possible cause for the conflict made up only $4 \%$ of references to causes in news articles.

A symbol of British culture at home and an ambassador of goodwill abroad, the publicly-funded $B B C$ aired its first radio broadcasts in 1922. Its services now include 
television and the news web site under study. The BBC World Service is funded by a Parliamentary grant-in-aid, administered by the Foreign and Commonwealth Office (FCO) of the UK government. During certain international crises (i.e., the Suez crisis, Northern Ireland, Iraq), the Foreign Office has intervened to shape news coverage. With more than 20,000 staff and 250 reporters around the world, the BBC casts a wide net of global news gathering. The BBC website published its first article that focused exclusively on the situation in Darfur a month after the rebellion started.

Predominant treatment of the causes of the crisis alone (without discussion of conduct or remedies) was found in only around $1 \%$ of the news articles; in combination with conduct and remedies, causes were discussed in 18\%. Background information about the conflict and its causes was readily accessible from the array of links along the right side of the page. When the types of causes were discussed, ethnicity and race differences were cited most often. This occurred most frequently in last-paragraph summaries or in passing comments. A significant textbox titled "Q and A: Sudan's Darfur Conflict" also addressed causes, providing updates on how, who, and why (BBC News, 2005). The most frequently-discussed cause was ethnicity and race differences, accounting for $56 \%$ of mentions in news articles. Discussions of ethnicity and race also appeared while the US and the UN deliberated over whether the conflict was genocide, ethnic cleansing, or something else. The second most frequently-mentioned category of causes was regional inequity (39\%). Articles mentioned environmental changes such as the expansion of the desert due to global warming in $4 \%$ of total causal mentions in news. These articles stated that many of the Janjaweed militia fighting for the lands of the agriculturist Darfuris came from villages adversely affected by climate change. Although "oil" was mentioned in the text of news articles and in one headline, it was not addressed as a cause.

\section{France's Le Monde}

In comparison to Egypt and China, France has low current national interests in Sudan. Like Britain, however, France does have a long history as a colonial power and continues to play a major role in its former colonies (e.g., Chad, Sudan's neighbor to the west). Darfur has been the rear base for many conflicts involving Chad, Libya, and France. France's foreign policy has been cautious on Darfur in comparison to the US; France supported multilateral initiatives through the UN and European Union (EU), initially stalling on taking a stand that would antagonize Sudan's military dictator and only gradually building up to firm support for the arrest warrant by the International Criminal Court.

Unique due to its employee ownership and its founding editor's fierce commitment to journalistic independence, Le Monde has nevertheless tended to analyze foreign crises and the role that France should play in resolving them in ways consistent with (or, some would say, supportive of) the government's position. Almost $11 \%$ of news articles focused predominantly on causes. Among possible story frames (causes of the crisis, conduct of the crisis, and remedies), causes were discussed alone or in combination with other frames in about $21 \%$ of the articles. Among causes, race and ethnicity were discussed most often, followed by regional inequity. Oil and environmental change were mentioned as causes in $4 \%$ of news articles. 


\section{The US' New York Times and Washington Post}

The Darfur rebellion of 2003 took place on Condoleezza Rice's watch in the Bush administration, when national actions in favor of universal humanitarian values were considered marginal. US national interests in Africa's largest country have been historically low when compared with its engagement with Russia, China, Taiwan, or the Koreas. Nevertheless, since Sudan's independence from the UK and Egypt in 1956, the US Central Intelligence Agency (CIA), the U.S. Agency for International Development (USAID), and the Chevron corporation have had a consistent presence (sometimes supportive, sometimes less so).

First printed in 1851, the New York Times has been part of the Ochs-Sulzberger family since 1896. The winner of more Pulitzer prizes than any other newspaper, the Times has been called (by the UK's Guardian) "the world's most revered newspaper" (Burkeman 2003). Less than $1 \%$ of news articles focused predominantly on the causes of the crisis. Only $17 \%$ of news articles addressed causes alone or in combination with remedies and conduct: it was the least frequently-used frame as against the daily conduct of the war and remedies to the crisis. The most frequently-mentioned cause was regional inequity ( $54 \%$ of mentions). Trailing quite far behind regional inequity as a cause were environmental change and ethnicity and race, accounting respectively for $23 \%$ and $21 \%$ of references to cause. The expansion of the desert was destroying grazing possibilities for the cattle-herding nomads, who were thus easy recruits into a military campaign that would get them new homes in Darfur's farming areas. Many articles described Darfur's landscape as harsh, lacking water, and unforgiving to local residents, who subsist from one day to the next.

The Washington Post Company, publishing since 1877, had been privately held by the Meyer-Graham family for over forty years before it went public in 1971. The family still has a controlling interest through a dual-class stock structure. Not a single article addressed causes predominantly; discussion of causes was combined with narratives on the conduct of the war and possible remedies. Almost every other news article presented a brief paragraph on the causes, especially the Khartoum government's disproportionately brutal effort to put down the uprising by Darfuri rebels protesting inequitable regional distribution of national wealth. The articles explained that indigenous African farmer populations who supported the rebels were being eliminated to give more grazing land to nomadic Arab herders suffering from the expansion of the Sahara desert. Of the 53 mentions of causes, $77 \%$ addressed regional inequity. Discussion of race and ethnic differences accounted for $15 \%$ of causes mentioned, while $8 \%$ of references to cause mentioned environmental change.

\section{Quatar's AlJazeera English}

Qatar is the world's third-largest exporter of oil and natural gas. After World War I, the UK recognized the Al Thani family as rulers of Qatar, a modernizing monarchy that values British education and culture. They have continued in power since, sending their children to boarding schools in the UK. The country's overall success means that it has no economic or territorial designs on Sudan. Both countries are overwhelmingly Sunni Muslim. Qatar's interest is in improving the global image of the Middle East and Sudan through brokering internal regional solutions within the Middle East. Its political soli- 
darity with Sudan was evident in its abstention (with China and the Russian Federation) from supporting UN Security Council Resolution 1706, which expanded the mandate of the UN Mission in Sudan to include Darfur. Qatar also opposed the International Criminal Court arrest warrant for Sudanese President Omar al-Bashir.

Started in 1996, Al Jazeera is owned by a member of Qatar's royal family and was started as a pan-Arab alternative to Western news sources. Al Jazeera rarely discusses politics within Qatar and the Gulf. In its first twelve years on the air, Al Jazeera was a major departure from nationalistic broadcasts originating in Middle Eastern countries where daily transmissions begin by celebrating the ruling group. The appointment of another member of the royal family as director general in September 2011 is likely to make it more like the official network of the Qatari foreign ministry (Hounshell 2011), especially in light of its support of the rebels in Libya and its relative silence on Bahrain. The English web site of Al Jazeera is reputed to operate somewhat autonomously from the Arabic channel. Four percent of news articles predominantly focused on causes; $24 \%$ of news articles combined attention to conduct and/or remedies with mentions of causes. Of these causal references, regional inequity, expressed in terms of Darfur's experience of economic marginalization and political exclusion by the Sudan government, got the most mentions (41\%). Environmental change accounted for $27 \%$ of references to cause. These articles described the years of conflict between nomads and farmers over scarce resources in the arid western region. Historical details about this dynamic were mentioned frequently. Discussion of causes related to differences in ethnicity and race also made up $27 \%$ of mentions of cause. This included the use of terms like "genocide" and "ethnic cleansing." These terms were used in articles on English.AlJazeera.net mainly to deny or dismiss their validity or to categorize them as a label that had been imposed on Sudan by outsiders.

\section{Foreign News as International Development Communication: Implications}

The assumption that motivated this enquiry is that foreign news has the potential to inform its audience (the public, foreign aid policymakers) of the root causes of underdevelopment, thus shaping the nature of foreign aid. But how did ten news organizations actually perform in terms of covering the causes of the Darfur rebellion against underdevelopment?

First of all, it should be noted that the western province of Sudan called Darfur and its protests would not exist for most people without foreign news.

Table 1 shows that each news organization constructed Darfur differently: the Darfur that the Washington Post built for metropolitan Washington was different from the Darfur that the People's Daily constructed for Chinese-speakers. In the 26 months under study, Egypt's Arabic-language daily Al-Ahram mentioned the crisis south of its border in the largest number of articles (1456) followed distantly by the BBC web site in Sudan's long-time colonizer the UK (398 articles). The New York Times mentioned Darfur in 337 articles followed by South Africa's Mail \& Guardian Online (191 articles), the Washington Post (182 articles), Qatar's English. AlJazeera.net (169 articles), France's Le Monde (116 articles) and the UK Guardian (99 articles). Despite Xinhua Chinese news agency staff based in Sudan, the state-run China Daily (79 articles) and People's Daily 


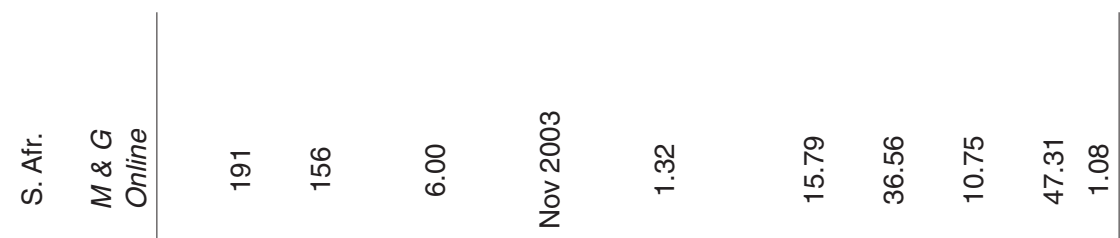

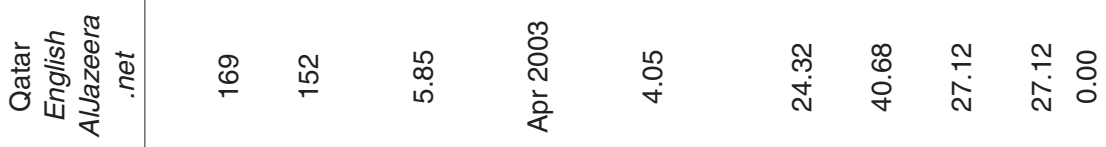

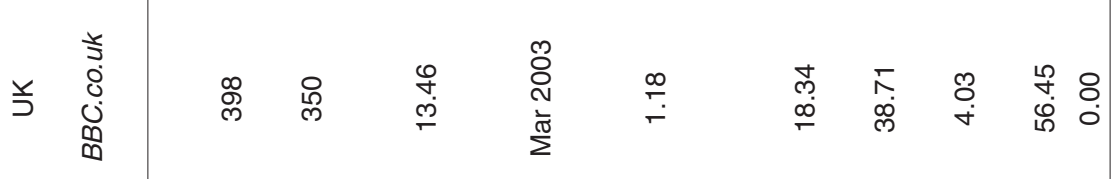

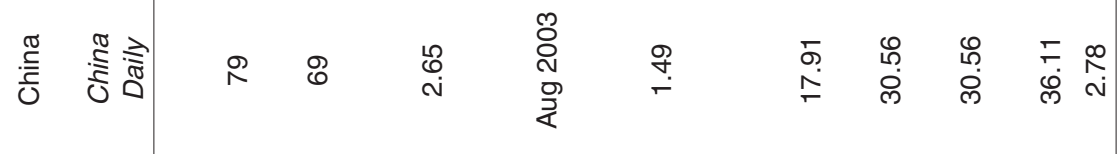

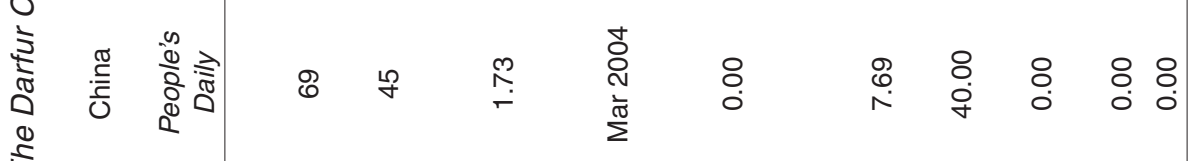

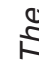

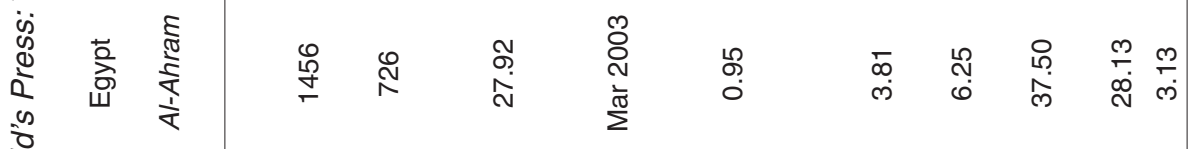
$\frac{1}{2}$

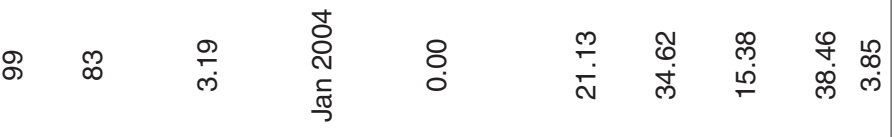

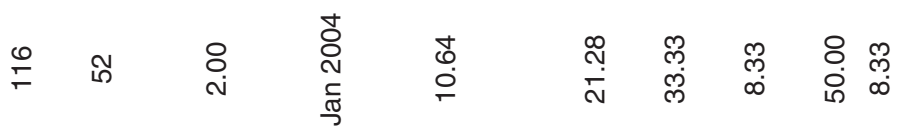

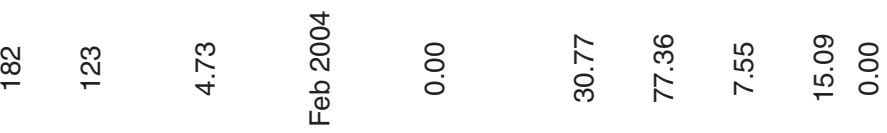

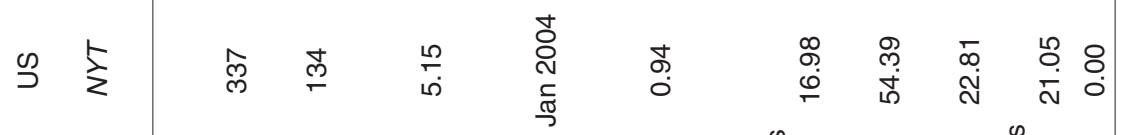

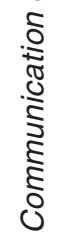


(69 articles) mentioned the Darfur rebellion least often of all ten news organizations.

There were few news articles that predominantly focused on causes, limiting information on to-be-expected growing pains in states born after World War II. Discussion of causes requires local knowledge and/or time for background research. The types of causes discussed ranged across regional inequity, environmental changes, ethnicity-race, and oil. Le Monde published the highest percentage of news articles focusing predominantly on causes (11\%) followed by English.AlJazeera.net (4\%); the Washington Post, UK Guardian, and People's Daily had none. When all discussions of causes (as the sole focus of articles and in combination with conduct and remedy foci) are added together, the findings show the highest scorers were the Washington Post (31\% of news articles), English.AlJazeera.net (24\%), Le Monde and the UK Guardian (both 21\%), and the UK's BBC.co.uk and the English-language China Daily (both 18\%).

What could national publics and policymakers learn about the causes of Darfur's tragedy that would shape the aid solutions it supported? Both US newspapers and English.AlJazeera.net discussed regional inequity causes most often, compared with environmental changes, ethnicity, and oil. Both former colonial powers UK and France discussed ethnic causes that might resonate best with their readers. So did China Daily, whose English-language readers are familiar with their ethnic minority problems with Uyghurs and Tibetans. People's Daily, edited for a domestic political-linguistic readership, avoided discussing this locally-sensitive issue. Egypt discussed environmental causes of the rebellion most often.

To sum up, there was one noticeable similarity across news organizations: the relative neglect of the causes of the Darfur crisis in comparison with discussion of the daily conduct of the rebellion and remedies. The limited attention to causes of underdevelopment and disparity is unfortunate, since foreign news is the only (albeit imperfect) means of sharing information on a large scale that could inform initiatives to help build states. Any form of discussion of causes ranged from a low of $4 \%$ of news articles in Al-Ahram and 8\% in People's Daily to a high of 24\% in English.AlJazeera.net and 31\% in the Washington Post.

Is the hope that knowledge provided by foreign news will lead to more enlightened long-term foreign aid policies a utopian dream with spurious universality? After all, different localities with distinct power structures and national interests are forces that shape how even their privately-owned news organizations construct media messages. More and wider provision of knowledge about underdevelopment (its causes, definitions, and consequences) is a desirable end in itself, and an investment against future genocides. International development communication and political researchers need to ask: under what macro, meso, and micro contextual conditions would disparate internet sites, a national news organization, or Rupert Murdoch's News Corp promote more and more detailed knowledge provision on the human condition? The overall study, The Geopolitics of Representation in Foreign News: Explaining Darfur (Mody 2010), found that each news organization made systematic, predictable news construction decisions on this particular topic (Darfur), bearing in mind who it is (ownership, intended audience) and where it is located in terms of national geopolitical history and current national interest. Ninety-five percent of the variation in comprehensiveness and timeliness of news was explained by the proposed geopolitical model consisting of ownership, geopolitical location, national interest in Sudan, and whether the audience was national or foreign. 


\section{Note}

1. Bella Mody, $\mathrm{PhD}$, is affiliated with the Journalism and Mass Communication Program at the University of Colorado in Boulder, USA. E-mail: mody@colorado.edu

\section{References}

Alozie, Emmanuel C. (2007) ““What Did They Say?' African Media Coverage of the First 100 Days of the Rwanda Crisis," in Allan Thompson (ed.) The Media and the Rwanda Genocide, London: Pluto Press.

Awad, Marwa (2010) Darfur donors raise \$841 mln, less than half target. Reuters Africa March 22, 2010. http://af.reuters.com/article/topNews/idAFJOE62K05620100322

Baddaley, M. (2011) Civil War and Human Development: Impacts of Finance and Financial Infrastructure. February http://www.econ.cam.ac.uk/dae/repec/cam/pdf/cwpe1127.pdf

BBC News (2005) “Q\&A: Sudan’s Darfur Conflict,” http://news.bbc.co.uk/1/hi/world/ africa/3496731.stm (accessed March 17, 2005).

Burkeman, Oliver (2003) ““All the News That's Fit to Print' - or So We Thought,” Guardian, May 13, 2003, http://www.guardian.co.uk/world/2003/may/13/usa.pressandpublishing (accessed February 25, 2008).

Carruthers, Susan L. (2004) “Tribalism and Tribulation: Media Constructions of 'African Savagery' and 'Western Humanitarianism' in the 1990s," in Stuart Allan and Barbie Zelizer (eds.) Reporting War, New York: Routledge.

Crocker, Chester A., Hampson, Fen Osler and Aall, Pamela (eds.) (2007) Leashing the Dogs of War, Washington, DC: US Institute of Peace.

Dewey, John (1927) The Public and Its Problems, New York: Holt.

Fine, Jon (2007) “These are Troubled Times," BusinessWeek, April 23, 2007, http://www. businessweek.com/ magazine/content/07_17/b4031030.htm (accessed December 1, 2008).

Hounshell, Blake (2011) “The end of the Al Jazeera decade?” Foreign Policy, September 20, 2011, http:// blog.foreignpolicy.com/posts/2011/09/20/the_end_of_the_al_Jazeera_decade (accessed Sept 30, 2011).

Huang, Peizhao (2004) "Darfur Crisis, Sudan Government Sought to Reconcile," People's Daily, August 26, 2004, http://www.people.com.cn/GB/paper464/12788/1149482. html (accessed June 9, 2007).

Kuperman, Alan J. (2000) “How the Media Missed Rwandan Genocide," International Press Institute Report Vol. 6, no. 1.

Lippmann, Walter (1922) Public Opinion, New York: Harcourt, Brace and Company.

Mamdani, Mahmood (2009) Saviors and Survivors: Darfur, Politics and the War on Terror, New York: Pantheon.

McCombs, Maxwell and Shaw, Donald L. (1972) "The Agenda-Setting Function of Mass Media," Public Opinion Quarterly Vol. 36, pp. 170-187.

Mody, Bella (2010) The Geopolitics of Representation in Foreign News: Explaining Darfur, Lanham, MD: Rowman \& Littlefield.

Price, Vincent and Czilli, Edward J. (1996) “Modeling Patterns of News Recognition and Recall," Journal of Communication Vol. 46, no. 2, pp. 55-78.

Robins, Melinda B. (2003) "Lost Boys and the Promised Land: US Newspaper Coverage of Sudanese Refugees," Journalism Vol. 4, no. 1, pp. 29-49.

Steeves, H. Leslie (1997) Gender Violence and the Press: The St. Kizito Story, Athens, Ohio: Ohio University Press.

United Nations Development Program (2005) Human Development Report 2005: International Cooperation at a Crossroads: Aid, Trade and Security in an Unequal World, New York: Oxford University Press.

Van Belle, Douglas A. and Rioux, Jean-Sebastein and Potter, David M. (2004) Media, Bureaucracies and Foreign Aid: A Comparative Analysis of the US, UK, Canada, France and Japan, New York: Palgrave Macmillan.

Wilkins, Karin and Mody, Bella (2001) "Reshaping Development Communication: Developing Communication and Communicating Development," Communication Theory Vol. 11, no. 4, pp. 385-396.

Xin, Jianqiang and Xu, Duo (2004) "Darfur Issue, What is Behind the Crisis?" People's Daily, October 18, 2004, http://www.people.com.cn/GB/paper464/13175/1181661.html (accessed June 9, 2007). 